\title{
ISLAM DAN MASA DEPAN HAK ASASI MANUSIA MENURUT ABDULLAH AHMED AL-NA'IM
}

\author{
Ita Musarrofa \\ Institut Agama Islam Negeri Sunan Ampel Jl. A Yani I I 7 Surabaya | \\ itaisme@gmail.com
}

\begin{abstract}
The reality of the modern world necessitates a Muslim to rethink about how to be a Muslim in the middle of the interdependence of security, politics, social and culture. This makes Abdullah Ahmed al-Na'im, a Sudanese Muslim intellectual, be restless. The provision of international legal guarantees for the implementation of the collective right of every nation to self-determination make Muslims play the majority of mobilizing their identity in the form of an Islamic state and the implementation of shari'ah itself. However, the affirmation of the collective right to self-determination must be placed within the framework of providing justice for all citizens regardless of sex, race and religion. Herein lies the problem of the implementation of Islamic shariah. It is because in some cases, the implementation of Islamic shariah actually violates Human Rights, especially the rights of women and non-Muslims. Al-Na'im seeks a peaceful path that Human Rights which established by the United Nations gets the legitimacy of Islam, so that the implementation of the collective right to selfdetermination by Muslims is not contrary to the values of Human Rights that have been declared universally.
\end{abstract}

Keywords: Human rights, universal, shariah, Abdullah Ahmed alNalim.

Abstrak: Realitas dunia modern meniscayakan seorang muslim untuk memikirkan kembali tentang bagaimana menjadi muslim di tengah interdependensi keamanan, politik, serta sosial budaya. Hal inilah yang menggelisahkan Abdullah Ahmed al-Na'im, seorang intelektual muslim asal Sudan. Pemberian jaminan hukum internasional atas pelaksanaan hak kolektif setiap negara untuk menentukan nasib sendiri, membuat muslim yang berposisi mayoritas memobilisasi identitasnya dalam bentuk negara Islam serta pelaksanaan syariah di dalamnya. Akan tetapi, penegasan hak kolektif untuk menentukan nasib sendiri (self 
determination) haruslah diletakkan dalam kerangka memberikan keadilan bagi seluruh penduduk tanpa membedakan jenis kelamin, ras dan agama. Di sinilah letak problem pelaksanaan syariah Islam, karena dalam beberapa kasus, pelaksanaan syariah Islam justru melanggar Hak Asasi Manusia terutama Hak Asasi Perempuan dan non-muslim. AlNa'im mengupayakan jalan damai agar Hak Asasi Manusia yang ditetapkan PBB mendapat legitimasi dari Islam, agar pelaksanaan hak kolektif untuk menentukan nasib sendiri oleh umat Islam tidak bertentangan dengan nilai-nilai Hak Asasi Manusia yang sudah dideklarasikan secara universal.

Kata Kunci: Hak Asasi Manusia, universal, syariah, Abdullah Ahmed alNa'im.

\section{Pendahuluan}

Saat ini kehidupan internasional dicirikan dengan interdependensi negara-negara bangsa. Apa yang dikenal dengan globalisasi telah menghancurkan sekat-sekat dan jarak antar bangsa. Selain itu, globalisasi juga membuat kesalingterpengaruhan dan kesalingtergantungan menjadi realitas yang sulit dihindari. Seorang muslim dihadapkan dengan pertanyaan tentang bagaimana menjadi seorang muslim di tengah interdependensi keamanan, politik dan ekonomi dan kesalingterpengaruhan sosial-budaya. Dengan kata lain, transformasi radikal yang terjadi dalam kehidupan saat ini berpengaruh pada persoalan bagaimana menjadi muslim di tengah-tengah modernitas.

Masalah utama yang dihadapi muslim modern selama dua abad terakhir adalah bagaimana menyesuaikan orientasi dan mentransformasikan konsepsi Islam dengan cara yang otentik dan legitimet. Apapun persoalannya, baik itu modernitas, demokrasi, HAM, perkembangan ekonomi atau masalah-masalah lain, persoalan utamanya pasti seputar kebutuhan akan legitimasi dan rasionalisasi tujuan normatif atau material tradisi masyarakat Islam. Upaya ini pula yang dilakukan Abdullah Ahmed al-Na'im, 
seorang pemikir Islam asal Sudan. ${ }^{1} \mathrm{Al}-\mathrm{Na}$ 'im, sehubungan dengan realitas transformasi radikal dunia, mempertanyakan kaitan antara HAM dan Islam. Pelanggaran HAM atas nama syariah Islam yang ia saksikan langsung di Sudan, membuatnya gelisah, benarkah Islam tidak kompatibel dengan HAM, benarkah Islam tidak adil.

Pertanyaan-pertanyaan tersebut menggugahnya untuk melihat syariah seperti apa yang melanggar HAM dan syariah yang mana yang seharusnya diberlakukan saat ini. Bagi al-Na'im, syariah historis -formulasi klasik- tidak lagi memadai untuk terus menjadi landasan hidup muslim modern. Diperlukan syariah baru yang lebih adil dan kompatibel dengan standar HAM universal. Upaya-upaya al-Na'im untuk membuat formulasi syariah baru ini inilah yang digagas dalam tulisan ini. Tulisan ini bermaksud melihat alternatif pembaharuan yang ditawarkan al-Na'im dalam rangka membangun otensitas dan legitimasi Islam bagi HAM universal.

\section{Self Determination: Batasan-Batasan bagi Upaya Penegasan Identitas}

Secara sosiologis, umat Islam memang mayoritas, paling tidak hal itu dibuktikan dengan jumlah umat Islam yang mencapai $70 \%$ dari keseluruhan jumlah penduduk di 35 negara. Meski demikian, ada kecenderungan umat Islam untuk menerjemahkan posisi

\footnotetext{
Al-Na'im lahir tahun 1946 di Sudan. la adalah seorang pemikir Islam yang memperjuangkan tegaknya hukum dan HAM. la memulai pendidikan formal di Fakultas Hukum Universitas Khortum tahun 1970 Sudan meraih gelar L.LB (Honoris), LL.M dan diploma kriminologi di Universitas Cambridge tahun 1973. selain itu ia juga pernah menjadi visiting profesor Hukum di departemant Hukum dpada Universitas California (1985-1987) dan Universitas Saskatchenwan di Sasketoon (1988-1989) serta visiting Proesor di Uppsala (1991-1992). Pengalaman karir akademik al-Na'im yang pernah dipegang diantaranya adalah Direktur Pelaksana Hak Asasi Manusia di Afrika (1993-19950, Direktur Pusat Kebijakan dan Hukum Internasional di New England School of Law dan Direktur Proyek riset, meliputi dua bidang: I. Bidang Kajian Perempuan Afrika, 2. Studi global tentang teori dan praktek hukum Islam di Fakultas Hukum Universitas Emory yang bekerja sama dengan Ford Foundation. Saat ini, al-Na'im menjadi Guru Besar Hukum pada Universitas Emory, Georgia, USA yang mengajar di bidang Hukum Kriminal, HAM dan Hukum Islam. Al-Na'im, Dr. Al-Na'im, http://www.crimesofwar.org. Diakses tanggal 20 Januari 2007.
} 
mayoritas secara sosiologis ke dalam arti politik. Penerjemahan itu berbentuk mobilisasi identitas Islam untuk mencapai sasaransasaran tertentu dari kebijakan publiknya. Fenomena inilah yang memunculkan isu penerapan syariah dan pembentukan negara Islam modern. ${ }^{2}$

Mobilisasi identitas Islam untuk mencapai sasaran tertentu merupakan bentuk pelaksanaan hak kolektif untuk menentukan nasib sendiri (self determination). Hak ini ditetapkan berdasarkan hukum kebiasaan internasional dan diakui oleh piagam PBB serta berbagai instrumen hak asasi internasional. Ia juga merupakan prinsip hukum internasional yang menekankan hubunganhubungan persahabatan dan kerja sama di antara negara-negara sesuai dengan piagam PBB. $^{3}$ Prinsip kesamaan hak dan menentukan nasib sendiri bangsa-bangsa didefinisikan sebagai berikut :

Karena prinsip kesamaan hak dan menentukan nasib sendiri bangsa-bangsa diabadikan dalam piagam PBB, semua bangsa mempunyai hak untuk secara bebas menentukan, tanpa intervensi pihak luar, status politik mereka dan untuk mengejar pembangunan ekonomi dan budaya mereka. Dan setiap negara memiliki kewajiban untuk menghormati hak ini sesuai dengan ketentuan piagam tersebut. Maksud prinsip-prinsip ini dan prinsip-prinsip lain dari hukum internasional yang dikuatkan dalam deklarasi ini dengan konsensus seluruh anggota PBB merupakan salah satu kepedulian terhadap hak-hak bangsa-bangsa untuk menegakkan identitas diri mereka dan hak untuk berusaha merealisir keadilan tanpa intervensi negara lain.

Dengan demikian hak kolektif untuk menentukan nasib sendiri dimaksudkan sebagai upaya internasional untuk

\footnotetext{
2 Meski dapat dipastikan umat Islam ada di setiap negara, tapi tidak bisa dipastikan jumlahnya. Karena itu data di atas cukup aman disajikan. Al-Na'im, Al-Na'im, Abdullahi Ahmed, Dekonstruksi Syari'ah, Wacana Kebebasan Sipil, HAM dan Hubungan Internasional dalam Islam, diterjemahkan oleh Ahmad Suaedy dan Amiruddin Arnami, cet 2 (Yogyakarta: LKiS, 1997), xix.

${ }^{3}$ lbid., 32I.
}

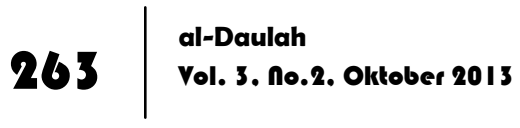


merealisasikan keadilan baik di lingkup nasional masing-masing negara maupun di lingkup internasional dalam hubungan antar negara.

Selain itu, kewajiban menghormati hak asasi manusia adalah bagian integral dari hak untuk menentukan nasib sendiri. Dengan kata lain, hak untuk menentukan nasib sendiri adalah hak suatu negara untuk menegaskan dan merealisasikan hak-hak asasi manusia bagi seluruh penduduknya tanpa membedakan ras, jenis kelamin dan agama. Bila ditarik ke dalam kasus Islam, pelaksanaan hak kolektif untuk menentukan nasib sendiri dengan identitas Islam haruslah tidak melanggar legitimasi hak perorangan dan kolektif pihak lain, baik di dalam maupun di luar komunitas Islam. ${ }^{4}$ Sebaliknya self determination dapat diwujudkan hanya melalui apresiasi yang mendalam atas interdependensi seluruh masyarakat manusia. ${ }^{5}$

Namun sayangnya, penegasan identitas Islam melalui pelaksanaan syariah historis ternyata bertentangan dengan Hak Asasi Manusia. Penegakan syariah historis justru mengancam umat Islam dan non-muslim. Dalam kasus Sudan misalnya, aplikasi syariah yang diperluas tidak hanya memperluas pelanggaran hak kaum perempuan ke wilayah selain hukum personal tetapi juga melanggar hak kaum non-muslim yang merupakan sepertiga jumlah penduduk Sudan. Ini karena syariah mendiskriminasikan baik perempuan maupun non-muslim dalam hal hak atas pekerjaan, kesetaraan di depan hukum, dan seterusnya.

Sebagai contoh, hak-hak perempuan akan pekerjaan dan partisipasi dalam kehidupan publik, kebebasan ruang gerak dan kebebasan berorganisasi, sangat dibatasi melalui kombinasi prinsip syariah mengenai qawamah (perlindungan laki-laki atas perempuan), hijab dan pemisahan antara laki-laki dan perempuan.

\footnotetext{
${ }^{4}$ lbid., 3.

${ }^{5}$ Al-Na'im, "Islam Politik dalam Kancah Politik Internasional dan Relasi Internasional", dalam Peter L. Berger, Kebangkitan Agama Menantang Politik Dunia, cet. I (Yogyakarta: Arruz, 2003), I 8 I .
} 
Perempuan juga didiskriminasikan dalam administrasi pengadilan sebagai contoh kesaksian yudisial perempuan direndahkan menjadi separuh dari nilai kesaksian laki-laki (dua perempuan diperlakukan sebgai sati saksi) dalam kasus perdata, dan tidak diterima sama sekali dalam kasus pidana serius. Dalam pembunuhan yang melawan hukum, kompensasi dalam bentuk harta yang dibayarkan kepada pewaris yang korbannya perempuan lebih kecil daripada konpensasi yang dibayarkan kepada pewaris yang korbannya laki-laki. ${ }^{6}$

Non-muslim juga menjadi sasaran pembatasan serupa melalui praktek yang umumnya dikenal sebagai dhimmah. Dengan sistem ini, para anggota komunitas non-muslim yang ditolerir hidup di dalam sebuah negara Islam dijamin perlindungan atas diri dan hartanya, hak untuk mengamalkan agamanya, dan mendapatkan tingkat otonomi komunal tertentu sebagai ganjaran atas ketundaukan mereka kepada pemerintah muslim serta pembayaran pajak kepala yang dikenal dengan jizyah. Menurut sistem dhimmah, non-muslim tidak diperbolehkan memegang jabatan publik yang akan membuat mereka memiliki otoritas atas kaum muslim dan tidak diperbolehkan bertugas dalam angkatan bersenjata sebuah negara Islam. Dalam administrasi peradilan pidana, kesaksian seorang saksi non-muslim tidak diterima dan konpensasi uang yang dibayarkan atas pembunuhan yang melawan hukum atas korban non-muslim lebih kecil daripada atas pembunuhan yang korbannya muslim. ${ }^{7}$ Selain itu, prinsip syariah yang memandang kemurtadan sebagai dosa besar dan menetapkan bahwa seorang muslim yang murtad harus dibunuh juga melanggar hak-hak fundamental atas kebebasan beragama.

\footnotetext{
${ }^{6}$ Abdullah Ahmed al-Na'im, 'Qur'an, Shari'a and Human Rights: Foundations, Deficiencies and Prospects', dalam Hans Kung dan Jurgen Moltmen, The Ethic of World Religions and Human Rights (London : Trinity Press International, t.t.), 63.

${ }^{7}$ Ibid., 166
} 


\section{Universalisasi HAM: Mungkinkah?}

Pelanggaran HAM karena agama dan gender tidak hanya terjadi di dalam Islam, Yahudi dan Kristen tapi juga dalam tradisi agama, budaya, bahkan ideologi lainnya. Hal ini terjadi, menurut al-Na'im, karena watak eksklusif ketiganya sebagai sistem nilai. Ketiga sistem nilai ini cenderung mendefinisikan 'self' (diri) dan 'other' (yang lain) dalam istilah yang negatif dan antagonistik. ${ }^{8}$ Komitmen terhadap satu sistem nilai tertentu didasarkan pada kepercayaan bahwa mengikuti ajaran-ajarannya akan mendatangkan ganjaran moral atau material tertentu. Selain itu, dalam kepercayaan tersebut juga terkandung keyakinan bahwa sistem nilai lain tak akan mendatangkan hal serupa. ${ }^{9}$

Ganjaran yang dijanjikan tersebut misalnya menjadi manusia bijak dalam kehidupan ini atau mendapat keselamatan dan masuk surga dalam kehidupan yang akan datang. Ganjaran-ganjaran tersebut tidak instan, melainkan sulit dibuktikan realisasinya dalam kehidupan. Karena itu untuk tetap meyakinkan penganutnya, digunakanlah cara-cara tertentu. Salah satu cara yang digunakan, menurut al-Na'im, adalah dengan melebihlebihkan kualitas dan kuantitas ganjaran yang mereka terima atau akan diterima dan menganggap rugi orang lain di luar sistem nilainya. Dengan cara ini masing-masing pemeluk suatu sistem nilai mengagungkan sistem nilainya sendiri dan menganggap musuh pemeluk sistem nilai lainnya. Mekanisme pertahanan diri semacam ini (self-vindicating defense mechanism) menyebabkan sindrom 'mereka' (them) dan 'kita' (us) melahirkan sikap bermusuhan dengan 'them' dan solidaritas dengan ' $u s^{\prime} .{ }^{10}$

Watak eksklusif agama, budaya dan ideologi yang seperti ini tentunya bukan iklim yang kondusif bagi terciptanya keadilan

${ }^{8}$ Abdullahi Ahmed Al-Na'im, "Toward an Islamic Hermeneutics for Human Rights", dalam Abdullahi Ahmed Al-Na'im, Jerald D. Gord, Hary Janen, Hendrik M Vroom (ed.), Human Rights and Religious Value an Uneasy Relationship?, (Amsterdam: William B. Eendmans Publishing Company, tt), 230.

${ }^{9}$ lbid., 231.

${ }^{10}$ lbid., 23l. 
internasional sebagai tujuan pendeklarasian hak kolektif menentukan nasib sendiri (Self determination). Sebaliknya self determination dapat dijadikan legitimasi melakukan agresi terhadap 'yang lain' (other) berdasarkan penegasan identitas agama, budaya dan ideologi. Dengan watak eksklusif ini pula, masing-masing individu, masing-masing mayarakat di suatu negara terancam menjadi korban pelanggaran HAM. Oleh sebab itu, karena adanya kesadaran akan kerentanan posisi masingmasing (a shared consciousness of vulnerability), maka menurut al$\mathrm{Na}$ 'im, diperlukan suatu konsensus universal yang diformulasikan secara netral, melintasi batas-batas agama, budaya dan ideologi.

Akan tetapi, mungkinkah konsensus universal HAM itu tercapai? Apakah mungkin konsensus universal mendapatkan legitimasi dari agama, budaya dan ideologi yang berbeda-beda? Suatu tindakan yang kontraproduktif, menurut al-Na'im, bila meminta masyarakat memilih antara agama, budaya dan ideologi yang mereka anut dengan proyek HAM universal yang diduga netral. Menurut al-Na'im, kebanyakan masyarakat pasti akan memilih yang pertama daripada yang kedua. Alasannya ada dua: pertama, bagi kebanyakan masyarakat, tidak ada skema HAM yang dengan sendirinya bisa menggantikan agama, budaya dan ideologi. Kedua, kebanyakan masyarakat akan menyatakan bahwa berbagai konsep HAM telah ada dalam agama, budaya dan ideologi mereka.

Meskipun demikian, standar universal HAM tetap memungkinkan karena adanya suatu prinsip normatif yang dimiliki semua tradisi kebudayaan besar yang menurut al-Na'im mampu menopangnya. Prinsip tersebut menyatakan bahwa seseorang harus memperlakukan orang lain sama seperti ia mengharapkan diperlakukan orang lain. Prinsip resiprositas seperti ini akan dengan mudah diapresiasi semua umat manusia. ${ }^{11}$ Selain itu menurut al-Na'im, HAM adalah hak yang diberikan

II Ibid., 310. 
karena kemanusiaannya yang menyangkut harkat dan kesejahteraan yang inheren pada setiap umat manusia tanpa membedakan ras, jenis kelamin, bahasa maupun agama. Tegasnya, ada dua kekuatan utama yang memotivasi seluruh tingkah laku manusia yaitu kehendak untuk hidup dan kehendak untuk bebas. Penerapan prinsip resiprositas pada dua hal inilah yang, menurut al-Na'im, menjadi dasar universalitas Hak Asasi Manusia dalam batas minimum. Selain itu, standar universal HAM juga dimungkinkan melalui multiidentitas atau identitas tumpang tindih (multiple atau overlapping identities). Dengan teorinya ini, al$\mathrm{Na}^{\prime} \mathrm{im}$ mengandaikan suatu pertingkatan identitas. Orang dapat memiliki identitas sebagai ' $u s^{\prime}$ (kami) tanpa harus memusuhi 'them' (mereka) pada suatu level identitas karena 'them' (mereka) dapat menjadi bagian dari 'us' (kita) pada level identitas lainnya. Untuk menjelaskan overlapping identities ini, al-Na'im mencontohkan kenyataan identitasnya sendiri: ${ }^{12}$

Saya seorang muslim dan mengidentifikasikan diri dengan umat Islam lainnya berdasarkan agama saya. Saya juga orang Sudan yang memiliki profesi tertentu dan berbagai kepentingan serta ketertarikan yang sama dengan orang Sudan lainnya, juga masyarakat di seluruh belahan dunia. Akhirnya, dan yang terpenting, saya adalah manusia yang berkomitmen untuk melindungi dan mendukung nilai dan kualitas kemanusiaan.

Prinsip resiprositas dan overlapping identities di atas adalah potensi yang dimiliki setiap tradisi agama, kultur ataupun ideologi untuk dapat membuat konsensus universal Hak Asasi Manusia. Selain potensi yang sudah inheren dalam masing-masing tradisi

12 overlapping identities dilegitimasi oleh al-Qur'an (49: 13). Ayat ini menurut pemaknaan alNa'im menyebutkan bahwa perbedaan manusia atau pluralitas tidak hanya inheren dalam skema Tuhan mengenai segala sesuatu tetapi juga sengaja didesain untuk mempromosikan kesalingpahaman dan kerjasama antar masyarakat yang berbeda-beda. Bagian akhir ayat ini menurut al-Na'im, menekankan bahwa kemuliaan manusia lebih ditentukan oleh perilaku moralnya daripada oleh keanggotaannya dalam suatu etnis, agama atau kelompok lainnya. Dengan memaknai ayat ini sebagai prinsip overlapping identities, al-Na'im melangkah lebih jauh dari penafsiran sebelumnya yang hanya menganggap ayat ini mengacu pada perbedaan dan pluralitas di dalam komunitas Islam saja dan bukan seluruh manusia. Ibid., 233. 
agama, budaya ataupun ideologi, menurut al-Na'im, perlu dilakukan upaya-upaya lain untuk membangun landasan kultural bagi HAM universal. Upaya yang dimaksud adalah dialog lintas budaya (cross-cultural dialogue) serta diskursus internal atau transformasi internal masing-masing tradisi agama, budaya atau ideologi.

\section{Perlunya Pembaharuan}

Dalam pendahuluan bukunya, al-Na'im menjelaskan problem normativitas dan historisitas, problem high tradition dan low tradition. Problem inilah yang membuat ia gelisah. Bagaimana hubungan antara Islam sebagai agama dengan formulasi Islam historis yang dikenal dengan syariah. Ia merasa tidak nyaman dengan tudingan bahwa ternyata syariah tidak memadai dan tidak adil, padahal syariah, oleh umat Islam, dianggap bagian dari keimanan. ${ }^{13}$ Kenyataan pelaksanaan syariah di negerinya, Sudan, serta dieksekusinya Mahmud Muhammed Taha, gurunya, adalah masalah lain yang mendesaknya untuk meninjau ulang syariah historis.

Untuk memahami hakikat formulasi Islam historis atau yang selalu disebut al-Na'im dengan syariah historis, al-Na'im merujuk pada konsep-konsep diskursus hermeneutik. ${ }^{14}$ Menurut al-Na'im pilihan dan penafsiran terhadap ayat al-Qur'an sangat dipengaruhi oleh orientasi sang penafsir. Umat Islam selalu berbeda-beda dalam memilih ayat sebagai legitimasi pendapatnya, termasuk dalam menafsirkannya. Inilah alasan mengapa dalam Islam terdapat banyak aliran teologi dan mazhab hukum serta banyak pendapat yang berbeda-beda dalam masing-masing aliran tersebut. Orientasi itu sendiri, menurut al-Na'im, adalah pengkondisian situasi eksistensial atau material (conditioning of the

\footnotetext{
${ }^{13}$ Al-Na'im, Dekonstruksi Syari'ah., xix.

14 Dalam mendefinisikan hermeneutik, al-Na'im merujuk Oxford Universal Dictionary yang menyatakan bahwa hermeneutik biasanya didefinisikan dengan seni atau ilmu interpretasi, khususnya teks dan umumnya dibedakan dari eksegesis, eksplanasi dan eksposisi. Al-Na'im, "Toward an Islamic Hermeneutics", 234.
} 
existential or material circumstances) pembaca al-Qur'an atau sumber tekstual lainnya. ${ }^{15}$ Artinya setiap orang selalu memahami teks dan mengambil implikasi normatifnya dalam kerangka pengetahuan dan pengalamannya terhadap dunia. Setiap orang dalam memahami dipengaruhi oleh persepsi kepentingan pribadi dalam konteks politik dan sosial ekonomi serta realitas hubungan internasional dan sebagainya. Realitas di luar membentuk penafsiran orang.

Meskipun demikian, orientasi seseorang dapat juga dipengaruhi oleh visi perubahan atau pembaharuannya dalam kondisi eksistensial atau material. Dalam artian ia tidak selalu sepenuhnya dipaksa oleh situasi. Ia dapat keluar dari bentukan situasi ekonomi, politik, dan sosial budaya yang melingkupinya. Dan untuk melihat bagaimana prospek pelaksanaan visi tersebut sangat tergantung pada kemungkinan sejarah (historical contingency). Apakah situasi intelektual, sosial, politik, dan ekonomi dalam masyarakat memungkinkan untuk menerima visi perubahan yang ditawarkan, inilah persoalannya.

Selain itu, setiap agama (dan tradisi tertentu dalam sebuah agama) memiliki kerangka kerja interpretasi sendiri (framework of interpretation). Kerangka kerja ini berupa serangkaian aturan menafsirkan, teknik, dan asumsi-asumsi pokok yang dianggap valid dan otoritatif oleh pemeluknya. Penafsiran bisa disebut benar jika sesuai dengan kerangka kerja interpretasi ini. Para penafsir kemudian mengklaim bahwa penafsirannyalah yang paling benar karena lebih konsisten dengan kerangka kerja interpretasi yang diterima. Di samping itu, penafsir lain menantang otoritas kerangka kerja interpretasi tersebut dan berusaha mencari alternatif lain. ${ }^{16}$

Dalam kasus Islam, pada masa awal, tak ada kriteria-kriteria tertentu yang harus dipegangi dalam proses penafsiran al-Qur'an atau berijtihad dalam mengambil norma-norma etika dan prinsip- 
prinsip hukum. Bahkan pendiri mazhab empat tidak mengklaim hak eksklusif dalam berijtihad. Mereka menyerahkan pada masyarakat untuk memilih dan menentukan sendiri. Jadi masyarakatlah kerangka kerja penafsiran yang hidup serta penentu dan mediator aturan-aturan interpretative, teknis, dan asumsi-asumsi pokoknya. Sayangnya, pada akhir abad ke-3 Hijriyah muncul isu pintu ijtihad yang dikatakan telah tertutup. Fenomena inilah yang mendorong Ibnu Taimiyyah dan lainnya berusaha mengetuk untuk membuka pintu ijtihad yang telah ditutup. Tetapi, menurut al-Na'im, mereka belum berhasil. Kegagalan ini terkait dengan historical contingency yang dijelaskan di depan. Kondisi sosiologis, politik dan ekonomi pada saat itu tidak siap untuk visi perubahan yang ditawarkan Ibnu Taimiyyah dan kawan-kawan.

Kesiapan sejarah (historical contingency) sangat tergantung waktu. Ketidaksiapan hari ini belum tentu tidak siap di masa akan datang. Generasi mendatang dapat meneruskan argumentasiargumentasi di konteks mereka sendiri dan ada kemungkinan berhasil jika pembaharuan yang dilakukan sesuai dengan ruang dan waktunya. ${ }^{17}$

Dari sini, al-Na'im menyimpulkan bahwa tidak ada pemahaman yang paling benar terhadap al-Qur'an atau konsepsi Islam sejak ia dipengaruhi oleh orientasi individual dan kolektif muslim. Karenanya, perubahan dalam orientasi muslim akan mengakibatkan perubahan pula dalam pemahaman mereka serta konsepsi Islam itu sendiri.

Orientasi inilah yang penting menurut al-Na'im untuk dibentuk agar bisa mendukung HAM universal secara aktif. Orientasi yang kondusif bagi dukungan HAM universal akan mempengaruhi penafsiran muslim terhadap al-Qur'an dan konsepsi Islam. 


\section{Pendekatan Antropologis terhadap Islam}

Dalam analisis di atas terkandung dimensi antropologis karena suatu penafsiran sangat terkait dengan konteks. Al-Na'im memandang perlu menganalisis dengan menggunakan pendekatan antropologis, baik terhadap al-Qur'an maupun Islam secara umum. Pendekatan ini dipilih berdasarkan hubungan dinamis antara al-Qur'an dan Islam di satu sisi dengan nature manusia - pengetahuan, imajinasi, perilaku, pengalaman dan lainlain di sisi lain. Paling tidak dua hal menurut al-Na'im yang bisa ditambahkan pada argumentasi pentingnya pendekatan ini diterapkan pada al-Qur'an dan Islam secara umum. Pertama, agen manusia tidak bisa dihilangkan dalam memahami al-Qur'an dan Sunnah dan dalam menggali norma-norma etika serta prinsipprinsip hukum dari sumber-sumber tersebut untuk mengatur perilaku individu dan hubungan sosial. Ali bin Abi Thalib sendiri mengakui pendapat ini dengan menyatakan bahwa al-Qur'an tidak bisa bicara, masyarakatlah yang berbicara atas namanya. Kedua, sebagaimana telah disebutkan, kompleksitas perbedaan dalam teologi dan yurisprudensi Islam menunjukkan adanya relasi yang dinamis antara sumber tekstual Islam di satu sisi dengan pengetahuan, imajinasi, dan pengalaman masyarakat muslim di sisi lain. ${ }^{18}$

Meskipun demikian, yang menjadi pertanyaan adalah, apa yang bisa disumbangkan pendekatan ini di dalam cara muslim memahami Islam dan memadunya dengan irama zaman? Menjadi fakta Tak terbantahkan bahwa situasi historis tertentu selalu mempengaruhi persepsi dan praktek prinsip Islam oleh muslim dahulu, lalu bagaimana konteks modern mempengaruhi persepsi dan praktek muslim sekarang? Atau, orientasi seperti apakah yang seharusnya digunakan seorang muslim untuk memahami alQur'an dalam konteks modern? ${ }^{19}$

18 Ibid., 236-237.

19 Ibid., 237. 
Menurut al-Na'im, orientasi muslim modern seharusnya berbeda dengan orientasi muslim awal karena adanya perubahan radikal situasi material dan eksistensial. Kehidupan hari ini berbeda dengan kehidupan yang lalu. Saat ini, muslim hidup di era globalisasi politik, ekonomi dan saling ketergantungan keamanan, kesalingpengaruhan sosial budaya. Konsepsi muslim tentang Islam dan upaya-upaya hidup sesuai ajaran Islam, haruslah dikondisikan oleh persepsi modern dalam konteks dunia yang telah berubah secara radikal. Apapun visi perubahan dan pembaharuan yang dimiliki muslim dalam realitas dunia saat ini haruslah didasarkan pada keadaan dan kondisi dunia ini, dalam artian mempertimbangkan fakta tentang interdependensi dan saling mempengaruhi. ${ }^{20}$ Masalah utama yang muncul kemudian adalah bagaimana cara mengadaptasikan orientasi muslim dan merubah konsepsi mereka tentang Islam dalam cara yang otentik dan legitimate.

Kaitannya dengan pertentangan antara syariah dan HAM universal telah banyak upaya dilakukan, di antaranya adalah dua kubu yang saling bertentangan. Yang pertama menginginkan semua perubahan yang diajukan harus sesuai dengan syariah, sementara yang lain mendasarkan pada standar HAM universal tanpa memperhatikan kesesuaiannya dengan syariah. Di sisi lain, ada pula kelompok yang berusaha mendamaikan antara syariah dan HAM universal. Al-Na'im dalam hal ini tidak memposisikan diri pada salah satu dari ketiga kubu tersebut. Baginya, justru otentisitas dan legitimasi Islam sangatlah penting bagi penerimaan secara luas dan efektif serta penerapan HAM universal. Dengan pendirian ini, ia berpendapat bahwa rekonsiliasi antara syariah dan HAM tidak mungkin dilakukan, karena syariah didasarkan atas perbedaan fundamental antara muslim dan non-muslim, dan muslim laki-laki dan perempuan. Sulit sekali bagi syariah untuk akur dengan HAM universal yang mendasarkan ketetapannya 
pada kemanusiaan manusia tanpa membedakan agama dan gender. Bila yang dibutuhkan adalah otentisitas dan legitimasi Islam terhadap serangkaian HAM universal maka untuk mencapainya diperlukan pembedaan antara Islam dan syariah.

\section{Reformasi dan Reformulasi Syariah Historis}

Syariah dan Islam bukanlah dua istilah yang identik. Sebagai suatu pemahaman manusia yang terikat dengan ruang dan waktu, syariah, kata al-Na'im janganlah diidentikkan dengan keseluruhan agama Islam. Sebagaimana dijelaskan di depan, seorang pembaca (reader) selalu memahami teks-teks al-Qur'an dan hadis serta menggali norma-norma etik dan prinsip hukum darinya dalam kerangka pengetahuan dan pengalamannya di dunia. Sejak pengalaman dan pengetahuan, bahkan dunia itu, berubah, maka menurut al-Na'im, Islam janganlah terus diikat dengan penafsiran yang partikular terhadap sumber-sumbernya tersebut. Kiranya benar jargon yang mengatakan bahwa Islam sesuai dengan segala ruang dan waktu. Artinya harus ada fleksibilitas dan perubahan di dalam memahami dan mengimplementasikan Islam sesuai ruang dan waktu. Jadi sangatlah mustahil, kata al-Na'im, untuk terus memberlakukan syariah yang diformulasikan ulama selama lebih dari 30 abad yang lalu, apalagi secara fanatik menganggapnya sebagai satu-satunya hukum Islam yang benar. Oleh karena itu, perlu reformasi dan reformulasi syariah sebelum ia diterapkan saat ini, sebagai kriteria penerimaan dan pelaksanaan sistem normatif HAM universal.

Pentingnya reformasi dalam diskursus Islam modern seringkali dialamatkan pada fikih daripada syariah. Untuk merubah ketetapan-ketetapan fikih yang dirasa problematik untuk zaman ini, tawaran yang diajukan adalah ijtihad. Walaupun demikian, ajakan untuk berijtihad, kata al-Na'im, jarang sekali diikuti oleh aplikasi aktual dan derivasi kongkrit prinsip-prinsip baru syariah. Untuk membangun otentisitas dan legitimasi Islam bagi HAM universal, ada dua hal yang perlu diperhatikan. 
Pertama, ayat-ayat al-Qur'an yang seringkali dijadikan dasar ketidakadilan gender sudah sangat jelas. Berhadapan dengan ayat yang sudah jelas, HAM universal tak memiliki posisi tawar sedikitpun. Kedua, sejak prinsip ijtihad tradisional hanya membolehkan penerapan ijtihad pada ayat-ayat yang belum jelas, maka ayat-ayat yang sudah jelas tidak bisa diutak-atik lagi. Padahal diskriminasi, menurut al-Na'im, didasarkan pada ayatayat yang sudah sangat jelas, seperti diskriminasi gender didasarkan pada QS. 4: 34.

Memperhatikan dua hal di atas, maka yang perlu pertama kali direformasi, menurut al-Na'im, adalah prinsip ijtihad tradisional sebelum ia digunakan untuk memecahkan persoalan inkompatibilitas syariah dan HAM universal. Karena konflik di antara keduanya disebabkan ayat-ayat al-Qur'an yang sudah jelas dan bukan sekedar fikih yang hanya sebagai pemahaman manusia.

Untuk mengatasi hal ini, al-Na'im berpendirian bahwa ijtihad tidak saja dapat diterapkan pada ayat-ayat yang tidak jelas, tapi bahkan pada ayat-ayat yang sudah jelas ijtihad tetap perlu. Pendirian ini mengikuti pendapat gurunya Mahmoud Muhammed Taha. Premis dasar Mahmoud Muhammed Taha adalah suatu pengujian secara terbuka terhadap isi al-Qur'an dan sunnah yang menghasilkan dua tahap risalah Islam, yaitu periode Makkah dan periode Madinah. Menurut Mahmoud, pesan Makkah merupakan pesan yang abadi dan fundamental yang menekankan martabat yang inheren pada seluruh umat manusia tanpa membedakan jenis kelamin, keyakinan keagamaan dan lain-lain. Pesan Makkah ditandai dengan persamaan antara laki-laki dan perempuan serta kebabasan penuh untuk memilih dalam beragama tanpa ancaman apapun. ${ }^{21}$

Akan tetapi, karena pesan periode Makkah ini ditolak dengan keras, Mahmoud menyimpulkan masyarakat belum siap melaksanakannya, maka pesan yang lebih realistik pada masa

${ }^{2 !}$ Al-Na'im, Dekonstruksi Syari'ah., 103. 
Madinah diberikan dan dilaksanakan. Pesan-pesan Makkah yang belum siap diterapkan dalam konteks sejarah abad ketujuh ditunda dan diganti dengan prinsip-prinsip yang lebih praktis yang diwahyukan dan diterapkan selama masa Madinah. Pesan Makkah ini hanya ditangguhkan pelaksanaannya dalam kondisi yang tepat di masa depan. ${ }^{22}$

Menurut Mahmoud, teks-teks al-Qur'an Madinah dan Makkah berbeda bukan karena waktu dan tempat pewahyuannya, melainkan karena perbedaan kelompok sasaran. Kata "Wahai orang-orang yang beriman" (yang sering digunakan dalam ayatayat Madinah) menyapa bangsa tertentu. Sedangkan "Wahai manusia" (ciri ayat Makkah) berbicara pada semua orang. ${ }^{23}$

Yang menjadi persoalan kemudian adalah apakah penghapusan teks-teks al-Qur'an yang lebih awal bersifat vital atau konklusif, atau apakah masih terbuka untuk dipertimbangkan kembali. Bagi Mahmoud, nasakh ini tidaklah permanen karena tidak akan ada gunanya pewahyuan teks-teks Makkah tersebut. Ia juga mengatakan membiarkan nasakh menjadi permanen berarti membiarkan umat Islam menolak bagian dari agama mereka yang terbaik. ${ }^{24}$

Dari segala upaya yang dilakukan al-Na'im dalam menghadapkan HAM universal dan tradisi Islam-tradisi dan modernitas-Al-Na'im lantas menyimpulkan bahwa siapapun yang menginginkan otentisitas dan legitimasi Islam bagi HAM universal, maka ia harus terlebih dahulu menyelesaikan keberatan-

${ }^{22}$ Dengan argumentasi seperti ini terkesan bahwa Allah tidak tahu kesiapan umat. Untuk menepis kesan seperti ini, Mahmoud menolak keras keterbatasan ilmu Allah dengan mengajukan dua alasan pewahyuan pesan Makkah. Pertama, karena al-Qur'an adalah wahyu terakhir dan Nabi Muhammad adalah nabi terakhir maka al-Qur'an harus memuat semua ajaran yang dikehendaki Allah untuk diajarkan. Kedua, demi martabat dan kebabasan yang dilimpahkan Allah kepada seluruh manusia. Sesuai dengan martabat dan kebebasan itu, Allah menghendaki umat manusia belajar melalui pengalaman praktis mereka sendiri dengan tidak bisa diterapkannya pesan Makkah yang lebih awal, yang kemudian ditunda dan digantikan pesan Madinah yang lebih praktis.

23 Ibid., 108.

${ }^{24} \mathrm{Ibid}$., I I 0. 
keberatan teologis, resistensi sosiologis dan politis sebelum mengajukan sebuah metodologi reformasi yang memadai.

\section{Penutup}

HAM sangat terkait dengan budaya lokal. Dalam arti bahwa standar-standar HAM untuk bisa diterima dan diimplementasikan membutuhkan legitimasi budaya lokal. Rakyat lebih punya keinginan mengikuti standar HAM tersebut apabila mereka menerima norma dan nilai yang mendasari standar tersebut sebagai norma dan nilai yang sah dan valid dari sudut pandang kebudayaan mereka sendiri. Dengan kata lain, semakin kuat legitimasi standar HAM, maka akan semakin diikuti secara suka rela oleh rakyat pada umumnya dan semakin baik pula implementasinya oleh organ resmi negara. Sebaliknya semakin lemah legitimasi standar HAM tersebut dalam pandangan mereka maka akan semakin sering dilanggar oleh penduduk dan semakin mustahil diberlakukan oleh negara.

Apa yang dilakukan al-Na'im melalui nasakh gaya barunya adalah sebentuk upaya membangun landasan kultural Islam bagi HAM universal. Agar dengan itu semua, HAM universal mendapat legitimasi Islam dan membuka kemungkinankemungkinan baru untuk diterima dan diterapkan sebagai bagian pelaksanaan ajaran Islam.

Meskipun demikian, dalam beberapa tulisan al-Na'im yang menjadi rujukan makalah ini, kritik yang dilakukan al-Na'im hanya ditujukan pada tradisi agama, budaya atau ideologi agar bisa sesuai dengan HAM universal. Ia tidak pernah membahas lebih jauh -apalagi mengkritik - ideologi-ideologi yang bermain di balik UDHR (Universal Declaration on Human Rights) yang ada saat ini yang dipandang al-Na'im sebagai standar. Dengan kata lain, al$\mathrm{Na}$ 'im tidak menempatkan UDHR dan tradisi agama, budaya atau ideologi dalam posisi yang setara. Konsekuensinya, yang harus dikritisi melulu tradisi agama, budaya atau ideologi yang ada. 
Terlepas dari semua itu, apa yang dilakukan al-Na'im ini, merupakan sumbangan yang berarti, yaitu membuat ajaran Islam yang universal menjadi inspirasi dalam menjawab tantangan zaman.

\section{Daftar Pustaka}

Al-Na'im, Abdullahi Ahmed. "Islam Politik dalam Kancah Politik Internasional dan Relasi Internasional" dalam Peter L. Berger, Kebangkitan Agama Menantang Politik Dunia, Yogyakarta: Arruz, 2003.

- "Toward an Islamic Hermeneutics for Human Rights", dalam Abdullahi Ahmed Al-Na'im, Jerald D. Gord, Hary Janen, Hendrik M Vroom (ed.), Human Rights and Religious Value an Uneasy Relationship?, Amsterdam: William B. Eendmans Publishing Company, tt.

-------. 'Qur'an, Shari'a and Human Rights: Foundations, Deficiencies and Prospects', dalam Hans Kung dan Jurgen Moltmen, The Ethic of World Religions and Human Rights. London : Trinity Press International, t.t.

-------. Dekonstruksi Syariah, Wacana Kebebasan Sipil, HAM dan Hubungan Internasional dalam Islam. diterjemahkan oleh Ahmad Suaedy dan Amiruddin Arnami, cet 2, Yogyakarta: LKiS, 1997. . http://www.crimesofwar.org. Diakses tanggal 20 januari 2007. 